\title{
CINERADIOGRAPHIC STUDIES OF SOME BLADDER-SPHINCTER DYSFUNCTIONS IN PARAPLEGIA
}

\author{
By P. Dollfus, M.D., L. Mole, M.D., R. Peter, B. Huber, M.D. and V. Fonlupt
}

Cinecystourethrography has been used quite frequently on normal subjects in the past 20 years. But little has been published on paraplegia, especially where micturition is concerned. Davidson, Morales and Becker, 1966; Peha, L. J., Comarr, A. E. and Bors, E., I968, have published reports dealing with this method of investigation.

Since I 967 we have studied the bladder-sphincter function in 33 cases of paraplegia (all catheter free), either after the acute phase in Colmar or check-ups, or during the course of medical or professional rehabilitation in Mulhouse.

Of these, I6 patients had a complete upper motor neurone lesion, II had an incomplete U.M.N. lesion; 2 patients had a complete lower motor neurone lesion and 3 a mixed complete U.M.N.L. and L.M.N. lesion. One patient had an incomplete lesion of the same type.

All patients' lesions are of traumatic origin except for three. The aim has been to study micturition patterns in relation to the neurological status, upper or lower neurone lesion, complete or incomplete, as close as possible to the normal conditions of life of these patients and not under artificial and often error and infection inducing conditions, such as cystograms, ice-water tests and other unphysiological, but sometimes necessary, methods.

\section{METHODS}

The studies were carried out in the radiological department of the Pasteur Hospital in Colmar by a Phillips image intensifier with a synchronous $16 \mathrm{~mm}$. camera using 24 or 12 frames per second. Only short flashes of cineradiography were used to lessen, as much as possible, the dangers of radiation. The films were developed in a very short time through the automatic developing processor and ready to be viewed within 15 minutes.

Two methods have been used: the intra-venous pyelogram and, rarely, the retrograde filling of the bladder (the catheter being removed immediately after).

\section{The I.V.P. Method}

One hundred $\mathrm{ml}$. of Urovision 58 per cent. are mixed in $100 \mathrm{ml}$. of distilled water and injected by perfusion within approximately 5 to 8 minutes. X-ray plates are taken after the injection, usually after 15 and 25 minutes, but kept to a minimum to avoid unnecessary radiation. The patient is then asked to drink according to the size of the screened bladder and the known usual bladder capacity so as to get a good filling. Usually 30 minutes to one hour is sufficient, the bladder content contrasted enough to be able to start the study. Kidney secretion, pyelo-ureteric cinetic activity is observed during the bladder filling using small periods of image intensifier viewing. 
The bladder and sphincters are then observed, the patient being placed on an oblique plane $\left(25^{\circ}\right.$ to $\left.35^{\circ}\right)$ to the horizontal and asked to use his or her usual method of voiding. Half-sitting of the patient is sometimes necessary; the quantity of urine is noted at each attempt. Flow rates have not been noted in detail but can only be approximately calculated knowing the quantity of urine passed and counting the film frames after their development.

\section{The Retrograde Method}

Retrograde filling of the bladder has been used in two cases. Fifty ml. of tepid $\left(25^{\circ} \mathrm{C} .-30^{\circ} \mathrm{C}\right.$.) Urovison are injected into a previously emptied bladder through a catheter which is immediately removed. The patient is then asked to drink and eat normally. $\mathrm{He}$ is required to empty his bladder at the normal scheduled micturition time, 2 to 3 hours after. Very good contrast pictures are then obtained; the presence of reflux, if suspected, can be studied especially in relation to voiding.

(Retrograde urethrography has been used once, demonstrating the presence of a patulous external sphincter, a papilloma and a tight permanently closed internal sphincter.)

When voiding occurs the change of the bladder form is studied according to the presence, or not, of detrusor action. In one case formation of an intermittent diverticula has been noted. The topography of the concentric contractions is also noted, as well as the lower ureter activity during the detrusor's systolic and diastolic phases.

The base plate activity is also studied, the opening of the internal sphincter being noted as: nil, moderate, complete, intermittent or permanent in correlation with the detrusor's systolic and diastolic periods. Not infrequently have we seen, in upper neurone lesions, the internal sphincter closing during the trigger point sollicitation period and during the initial bladder contractions. The permanent, so-called 'funnel neck' deformity has been found in only one patient (a complete below Ti I upper motor neurone lesion).

The external sphincter has been our greatest problem in upper motor neurone lesions, or in mixed, upper and lower motor neurone lesions. Its relaxation in correlation with the bladder and the internal sphincter activity is noted as: synchronous, non-synchronous, or intermittently synchronous. The importance of its widening is also noted. Agreeing with many authors one can now speak of 'spasticity' of the external sphincter inducing a 'spurting' micturition. The help of pudendal nerve anaesthesia performed on the radiological table has been used once, but is certainly a method of the future.

The opening, or not, of the bladder neck must be noted in relation to the bladder form before and at the time urine is passed. Its widening can be sometimes difficult to assess.

\section{(Projection of a $16 \mathrm{~mm}$. film.)}

\section{RÉSUMÉ}

Le comportement habituel mictionnel de la vessie chéz le paraplegique a été étudié dans 33 cas. 2 méthodes sont utilisées. La lère grâce à l'urographie intraveineuse par perfusion, la zème par remplissage rétrograde de la vessie, la sonde est immédiatement 
enlevée. Une véritable spasticité du sphincter externe semble être le principal facteur de rétention dans les lé sions centrales. Le sphincter interne est lui le principal responsable dans les lésions périphériques. L'étude cinéradiographique de la miction éclaire le mécanisme mictionnel de certaines lésions dites 'mixtes' et doit être répétée après les interventions sur les sphincters. L'examen doit être aussi court que possible afin d'éviter les dangers d'irradiation.

\section{ZUSAMMENFASSUNG}

Wir glauben, dass die Untersuchung der vesico-sphinkterischen Aktivität in allen Fällen notwendig ist und dass, mindestens zur Zeit, Cineradiologie eine unschätzbare Untersuchungsmethode in Gemeinschaft mit anderen klassischen radiologischen Methoden darstellt.

\section{CONCLUSION}

We think the dynamic study of the vesico-sphincteric activity is a necessity in all cases and, that at least for the time being, cineradiology is an invaluable method of investigation in association with other classical radiological methods.

\section{REFERENCES}

Davidson, A., Morales, P. \& Becker, M. (1966). F. Urol., 96, I89-I93.

PeHA, L. J., ComarR, A. E. \& Bors, E. (1968). The American fournal of Roentgenology, Radium Therapy and Nuclear Medicine, Vol. CIV No. 2, October. (Urovison manufactured by Schering, A. G., Berlin.)

\section{Discussion}

DR. J. J. Walsh (G.B.). First of all, I thoroughly enjoyed seeing the film of Dr. Paul Dollfus. I don't think I've ever seen a film that was more beautifully done or I think more useful from the physiology and the physiopathology of a problem we have to deal with all the time. I was interested in two things; one is the value to him of the TUR., the internal sphincterotomy, in the low lesions, and I was glad to hear that he is thinking of an external sphincterotomy for his T2 lesion. Several years ago Mr. Cosbie Ross wrote a paper which laid down certain principles and, more than that, certain practical approaches to these problems. For a long time here, and in other places, some of us were frightened to do this. In the last two years, I have been doing it, and I can only thank Mr. Cosbie Ross for laying down such a very clear method of treatment for this difficult problem. Naturally, we wanted to improve on this, if we could, and I thought we would have a short cut, and in two or three cases I did an external sphincterotomy first. Somehow, it didn't work, except in one case, and I have now fallen back on Mr. Cosbie Ross's recommendations; we do a TUR.; if it doesn't work we do an external sphincterotomy. But again, I would like to congratulate Paul Dollfus on a really wonderful film.

MR. CosBie Ross. I would like to say how much I enjoyed the film, and clearly these films are not always a success but this one really showed the whole process of micturition in a very brilliant way. I am very interested to hear Dr. Dollfus also say that he has found that, when an obstructive lesion is found, it is not at the internal sphincter level, but it is lower down. This is part of the growing evidence that there is now from the States, and Mr. Walsh has just confirmed it here, for something which we have been saying since 1956 at Southport that the level of the obstruction is nearly always at the external sphincter level and not at the bladder neck. And, I understand 